\title{
SOME THOUGHTS ON A MORE HUMANIST AND EQUITABLE LEGAL EDUCATION
}

\section{A. WAYNE MACKAY*}

This article starts with the premise that all teaching is a communication of values between student and teacher. An important challenge in confronting law is making it more inclusive and equitable. A critical step in this process is first recognizing one's own biases. Only then will genuine dialogue about the inherent biases in the legal profession and in law schools be possible. Making law schools more inclusive entails not only superficial changes, but an examination of what is taught, how it is taught and how students are evaluated.
Le présent article postule que tout enseignement est la communication de valeurs entre élève et maûtre - un défi important en matière de droit étant de le rendre plus inclusif et équitable. Une des étapes critiques de ce processus est d'abord de reconnaitre ses propres préjugés. C'est alors que devient possible un authentique dialogue sur les préjugés propres à la profession et à l'enseignement de droit. Viser une plus grande ouverture des facultés de droit n'implique pas seulement des changements superficiels, mais aussi un examen des programmes, des approches pédagogiques et de l'évaluation des élèves.

TABLE OF CONTENTS

I. EDUCATION AS COMMUNICATING VALUES $\ldots \ldots \ldots .920$

II. EQUITY AS AN INTEGRAL PART OF

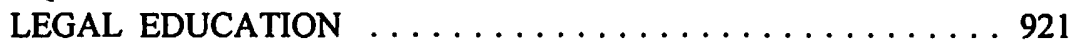

III. THE NEED FOR HUMANISM OR

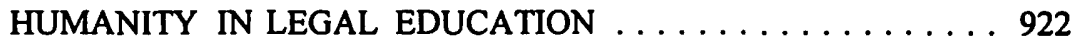

\section{EDUCATION AS COMMUNICATING VALUES}

At its core, any serious education is about the communication of values. This sharing of values should be a dialogue between the teacher and the student which will assist both parties in acknowledging what their values are and in challenging them. Everything we do as teachers is a reflection of our values: the kind of objectives that we set for our courses, the materials we select, the teaching methods we adopt and the way we evaluate.

Good teaching is not about clever pedagogical tricks and devices, but about engaging our students in a genuine and critical dialogue regarding the nature of law and its role in society. To have credibility in this dialogue, the law teacher should not hide behind the mask of "objectivity," but should acknowledge his or her own values and perspectives on the law.

This is a task of considerable self-reflection at both the rational and emotional level. For most of us, it would involve a recognition that we have been the beneficiaries of "white privilege," and that this has affected our values in countless ways. The need to address this prevailing context of white privilege is well articulated in an article by 
Peggy MacIntosh, "Unpacking the Invisible Knapsack of White Privilege."' Like the air we breathe, we are surrounded by white privilege but fail to take account of it.

What are the values that most law teachers and law students bring to the task of legal education? Let me suggest a few:

(1) Eurocentrism.

(2) Male perspectives (sexism).

(3) Heterosexism.

(4) An abled-body set of standards.

(5) White privilege (racism).

(6) High socio-economic status.

It is little wonder that people who have been traditionally excluded from legal education find the law school such an alien and even hostile place. I became acutely aware of this problem as the first director of Dalhousie's Indigenous Black and Micmac Program. ${ }^{2}$ During those years I learned much from the Black and Micmac students, as well as from the members of the larger communities which advised me on the operation of the program.

It is a humbling but ultimately rewarding experience to acknowledge one's own biases and limitations. It is also a vital first step in the process of communicating values. It underscores the magnitude of the transformative process that is needed to make legal education truly "inclusive." Before we can think seriously about transforming students, law schools or societies, we must honestly assess how much we have transformed ourselves.

This process of communicating values operates as much or more by example than by precept. Students can quickly assess whether their teachers merely talk a good line or also "walk their talk." If we as law professors do not practice what we preach, students will learn about hypocrisy and not about the need for change. There will always be inconsistencies but we should strive to reduce them.

\section{EQUITY AS AN INTEGRAL PART OF LEGAL EDUCATION}

One of the great challenges facing law, in all its forms, is becoming more inclusive and equitable. This is a challenge which is particularly appropriate for the legal academy. For the last three years I have had the good fortune of being involved in the Law Teaching Clinic, the focus of which has been the wedding of equity and legal pedagogy. This is a vital part of producing an inclusive, or as Richard Devlin calls it, an other legal education. I would urge that the Council of Law Deans continue to support this vital enterprise. 
We now have a number of access programs across the country and are beginning to have a more inclusive student body. There are also some modest efforts to have a more inclusive professorate, but we still have a long way to go. However, we must do more than change the face of the law school; we must reexamine some of its core values. Equity considerations must be central in:

(1) what we teach,

(2) how we teach, and

(3) how we evaluate.

Equity must not be an afterthought but must be at the heart of the legal education project.

\section{THE NEED FOR HUMANISM OR HUMANITY IN LEGAL EDUCATION}

Law is often presented as a rational discourse and the value of feelings and emotions are often downplayed. Too often, students are encouraged to "think like a lawyer" by abandoning their prior ways of thinking, feeling and knowing. When I started teaching law in the early 1980s, I wrote an article about the importance of humanism in promoting legal competence. ${ }^{3}$ I began the article with a quote from a poem by Denise Levertov called "Intrusion."

After I had cut off my hands and grown new ones, something my former hands had longed for came and asked to be rocked. After my plucked out eyes had withered and new ones grown, something my former eyes had wept for came asking to be pitied."

Surely one does not need to sever hands that can rock or eyes that can pity in order to be a lawyer, but there is more plucking and severing in law schools than we would care to admit. This loss of the former self is particularly felt by students who have traditionally been excluded. To appreciate this point, consider a brief poem by the Micmac poet, Rita Joe, entitled, "I Lost My Talk":

I lost my talk

The talk you took away.

When I was a little girl

At Shubenacadie school,

You snatched it away:

I speak like you

I think like you

I create like you

The scrambled ballad, about my word, 160.

Ibid. at 160 . 


\author{
Two ways I talk \\ Both ways I say, \\ Your way is more powerful. \\ So gently $I$ offer my hand and ask, \\ Let me find my talk \\ So I can teach you about me.
}

We must think very carefully not only about what we give to law students but also about what we take away. Our students come to us not as empty vessels to be filled but as fully formed people with values of their own. It is our duty to respect these values and to do our best to understand them. The aboriginal American author, Louise Erdrich, puts the challenge eloquently in her new book, The Bingo Palace:

We do know that no one gets wise enough to really understand the heart of another, though it is the task of our life to try.

Without the human link between teacher and student founded upon a respect and caring for that student, there is little hope for transformative education and a more inclusive legal education.

An unknown path opens up before us, an empty trail shuts behind. Snow closes over our tracks and then keeps moving like the tide. There is no trace where we were. Nor any arrows pointing to the place we're headed. We are the trackless beat, the invisible light, the thought without a word to speak. Poured water, struck match. Before the nothing, we are the moment.'

Let us seize the "moment" to make legal education more inclusive. 